\title{
Research on the Accounting Treatment for Different Types of Company Stock Investments and Their Related Performances Under the Accounting Standards in China
}

\author{
Yu Liu \\ Dalian Neusoft University of Information \\ Dalian, China \\ Minghong Sun \\ Dalian Neusoft University of Information \\ Dalian, China
}

\author{
Yunlong Qu \\ Dalian Neusoft University of Information \\ Dalian, China \\ Yadan Zhao \\ Dalian Neusoft University of Information \\ Dalian, China
}

\begin{abstract}
An increasing number of corporations are investing in the stock market nowadays. Prior studies focused on discussing either long-term equity investment or the invested stocks on which the investor company does not have significant influences. Corporations may invest in an individual stock directly or indirectly through stock investment portfolios. Investing in bank financial products is prevalent for listed firms in China as well. This paper summarizes different types of stock related investments and researches on how these invested stocks' performances affect the investor companies' financial performances in a systematic way. This paper also compares Corporate Accounting Standard No.22 for Enterprises Recognition and Measurement of Financial Instruments in $\mathbf{2 0 0 6}$ with the revised new accounting standards in 2017.
\end{abstract}

Keywords—stock investment; financial assets; performance; accounting treatment; accounting standards

\section{INTRODUCTION}

In the Chinese A-share stock market, there is an increasing trend for publicly listed corporations to invest in other A-share stocks today [1]. Some of the stocks are invested for the long-term merger and acquisition purposes, and the stocks are recognized as the long-term equity investments, according to Corporate Accounting Standard No.2 for Enterprises in China [2]. However, some of the stocks are invested without significant influences on the investees, and such invested stocks are recognized as different types of financial assets according to Corporate Accounting Standard No.22 for Enterprises- Recognition and Measurement of Financial Instruments [3]. Prior studies emphasized on either long-term equity investments or stock investments without significant influences on the investees. Few studies summarized accounting treatments for different types of stock investments' recognitions and their performance measurements in a systematic way.
Different companies make different types of stock related investments. Companies can invest in the other A-share stocks directly or indirectly through investment portfolios. Different types of stock investments are recognized in different types of accounts on the balance sheet. For example, Shanghai RAAS Blood Products Co., Ltd invested heavily in fund trust plans. Some of its investments are recognized as trading financial assets, while others are recognized as the long-term equity investments [4]. However, Changsheng Bio-technology Co., Ltd invested in bank financial products, which are recognized as the other current assets on the balance sheet [5]. Investments recognized in different types of asset accounts influence company financial performances in different ways. As more and more companies are making stock investments, it is important to distinguish different types of stock investments and make proper accounting treatments accordingly.

As for contributions of this paper, first, the paper summarizes different types of stock related investments in a systematic way. Second, both the accounts on the balance sheet and the accounts on the income statements, which are used to recognized different types of stock investments and their profitable performances, are discussed. Third, Corporate Accounting Standard No.22- Recognition and Measurement of Financial Instruments was revised and reissued by Ministry of Finance of the People's Republic of China in 2017, and new accounting standards are put into practice for all listed companies in China in 2019[6]. Comparisons of the original accounting standards in 2006 with the new accounting standards in 2017 are made, and the influences of the new accounting standards are analyzed in this paper. 


\section{INVESTMENT ACCOUNTS RELATED WITH STOCK INVESTMENTS AND HOW THEIR PERFORMANCES ARE RECORDED}

\section{A. Long-term Equity Investment and Performance Reporting}

Companies often make long-term equity investment for strategic merger and acquisition purpose. According to Corporate Accounting Standard No.2 for Enterprises (2014), if the investor controls or can exert significant influence on the investee, the related investment is recognized as a longterm equity investment. Generally speaking, if an investor holds $50 \%$ of the total shares of the investee company, the investor controls the investee and the investee becomes a subsidiary of the investor. However, if the investor holds more than $20 \%$ and less than $50 \%$ of the shares in the investees, the investor has significant influence on rather than controls the investee. On this occasion, the investor becomes either a cooperative enterprise or a joint operation.

An investor company can profit from the investee company's profit, dividend and disposal. If the investee company becomes a subsidiary of the investor company, the profit of the investee company is merged with that of the investor company at the end of the accounting period, according to Corporate Accounting Standard No.33 for Enterprises-Combined Financial Statements(2014)[7]. The income from the disposal of the investee company is a part of the investment income for the investor company and also for the combined group. The dividend income from the subsidiary is recognized as an investment income for the investor company. However, the dividend income from the subsidiary to the investor is a type of internal transaction, and the dividend is then adjusted at the end of the accounting period.

If the investor company has significant influence on the investee company rather than controls the investee, the financial statements of the investee are not combined with those of the investor company. Both the profit of the investee and the disposal income of the investee are investment incomes of the investor company. Other comprehensive income (OCI) from the investee company increases the investor company' OCI accordingly. Nevertheless, the investee dividend is used to decrease the long-term equity investment account of the investor company. The following "Table I" summarizes the relevant accounts on the balance sheet and the income statement, and compares how the investor accounts change with the performances of the investees for long-term equity investment.

TABLE I. LONG-TERM EQUTT INVESTMENT AND PERFORMANCE ACCOUNT SUMmARY

\begin{tabular}{|c|c|c|c|}
\hline Investment type & $\begin{array}{c}\text { Account on balance } \\
\text { sheet }\end{array}$ & Investee type & Account on income statement \\
\hline \multirow[t]{2}{*}{$\begin{array}{ll}\text { Strategic } & \text { M\&A purpose } \\
\text { with } & \text { control or } \\
\text { significant influence }\end{array}$} & \multirow[t]{2}{*}{$\begin{array}{l}\text { Long-term } \\
\text { investment }\end{array}$} & $\begin{array}{l}\text { Subsidiary } \\
\text { corporation (under } \\
\text { control) }\end{array}$ & $\begin{array}{l}\text { Subsidiary Profit: Increase group profit } \\
\text { Subsidiary Dividend: Increase investor investment income } \\
\text { (internal transaction) } \\
\text { Subsidiary Disposal: Increase group investment income }\end{array}$ \\
\hline & & $\begin{array}{l}\text { Investee } \\
\text { Cooperative } \\
\text { enterprise } / \text { joint } \\
\text { operation } \\
\text { significant } \\
\text { influence) }\end{array}$ & $\begin{array}{l}\text { Investee Profit: Increase investor investment income } \\
\text { Investee Dividend: Decrease investor long-term equity } \\
\text { investment } \\
\text { Investee Disposal: Increase investor investment income } \\
\text { Investee OCI: Increase investor OCI }\end{array}$ \\
\hline
\end{tabular}

\section{B. Stock Investment Without Significant Influence on Investees and Performance Reporting}

1) Accounting treatment under accounting standards in 2006 in China: According to Corporate Accounting Standard No.22 for Enterprises in 2006[8], if a company invests in other stocks for short-term profiting purpose, the investment is recognized as a trading financial asset. However, if a company invests in other stocks for profiting purpose but does not intend to sell the stock in a short time, the investment is recognized as an available-for-sale financial asset [9]. If the fair value of the invested stocks can be determined reliably, the investments should be measured on the fair value basis [6]. When the financial assets are sold, the increased fair value of the stock is realized and then turns into investment income, which is recognized as a type of profit.

An investor company can profit from the investee company's increased fair value, dividends and disposal incomes. As for trading financial assets, all of the investee's increased fair value, dividends and disposal incomes add to the investor company's investment income that helps raise the investor profit on the income statement. By contrast, as to available-for-sale financial assets, the dividend and disposal income of the investee company increase the investment income of the investor company. However, the increased fair value of the investee company raises the investor's other comprehensive income (OCI) rather than the investor's profit. In other words, when the available-for-sale financial assets are held by the investor, the increased value of the investment is recorded in OCI. However, when the financial assets are then sold out, the increased fair value is recognized as investment income and recorded in profit.

Based on prior studies, the investor company conducted earning management by taking advantage of the different accounting treatments for unrealized income [10]. The difference in the accounting treatments also causes trouble, when we try to choose a proper method to evaluate stock investment performances [11]. These accounting standards are then revised in 2017. "Table II" summarizes the accounts related to financial assets and how the related investor 
investment without significant influence in this way from the year 2007 to 2017 . accounts change with the performances of the investee's financial assets. Listed companies in China reported stock

TABLE II. STOCK INVESTMENT Without SignIFICANT INFLUENCE AND PERFORMANCE ACCOUNT SUMMARY

\begin{tabular}{|c|c|c|c|}
\hline $\begin{array}{c}\text { Investment } \\
\text { type }\end{array}$ & $\begin{array}{c}\text { Account on balance } \\
\text { sheet }\end{array}$ & Investee type & Account on income statement \\
\hline \multirow[t]{2}{*}{$\begin{array}{l}\text { Stock } \\
\text { investment } \\
\text { without } \\
\text { significant } \\
\text { influence }\end{array}$} & Trading financial assets & $\begin{array}{l}\text { Short-term investment in the A-share } \\
\text { market (without significant influence) }\end{array}$ & $\begin{array}{l}\text { Fair Value Increases: Increase investor investment } \\
\text { income (a type of profit) } \\
\text { Dividend: Increase investor investment income } \\
\text { Disposal: Increase investor investment income }\end{array}$ \\
\hline & $\begin{array}{l}\text { Available-for-sale } \\
\text { financial assets }\end{array}$ & $\begin{array}{l}\text { Stock investment that cannot be } \\
\text { classified into other financial assets } \\
\text { (without significant influence) }\end{array}$ & $\begin{array}{l}\text { Fair Value Increases: Increase investor OCI (rather } \\
\text { than profit) (OCI becomes profit when fair value is } \\
\text { realized) } \\
\text { Dividend: Increase investor investment income } \\
\text { Disposal: Increase investor investment income }\end{array}$ \\
\hline
\end{tabular}

2) Changes of financial assets reporting under accounting standards 2017 in China: Corporate Accounting Standard No.22 for Enterprises- Recognition and Measurement of Financial Instruments was revised and reissued by the Ministry of Finance of the People's Republic of China in 2017. There are several main changes related to the financial assets under the new accounting standards. First, the revised accounting standard regulates that all of the invested stocks need to be measured on the fair value basis [3]. However, such a conduct may be problematic for the stock investment whose fair value cannot be obtained reliably. Second, the invested stocks, which were originally recorded in either trading financial assets or available-forsale financial assets under the accounting standards in 2006, need to be reclassified into either the account of "financial assets measured at fair value whose changes are included in current profits and losses" or the account of "financial assets measured at fair value whose changes are included in other comprehensive income" [11]. Third, the reclassification is based on investee's business mode and cash flows under the new accounting standards rather than based on the investor's management intended holding period under the original accounting standards. In this way, the financial asset classification becomes more objective than before. More importantly, the problem caused by the different treatments of unrealized income is solved. The prior earning management problem [10] and evaluation problem [11] are solved. The revised accounting treatments are summarized in "Table III". The new accounting standards began to take effect in 2018 and are put into practice for all the listed companies in China in 2019.

TABLE III. Revised InVestment Without SignificAnt Influence And Performance ACCount Summary

\begin{tabular}{|l|l|l|}
\hline \multicolumn{1}{|c|}{ Investment type } & \multicolumn{1}{|c|}{ Account on balance sheet } & \multicolumn{1}{c|}{ Account on income statement } \\
\hline $\begin{array}{l}\text { Stock investment without } \\
\text { significant influence }\end{array}$ & $\begin{array}{l}\text { Financial assets measured at fair value } \\
\text { whose changes are included in current } \\
\text { profits and losses }\end{array}$ & $\begin{array}{l}\text { Fair Value Increases: Increase investor investment income } \\
\text { (a type of profit) } \\
\text { Dividend: Increase investor investment income } \\
\text { Disposal: Increase investor investment income }\end{array}$ \\
\cline { 2 - 3 } & $\begin{array}{l}\text { Financial assets measured at fair value } \\
\text { whose changes are included in other } \\
\text { comprehensive income }\end{array}$ & $\begin{array}{l}\text { Fair Value Increases: Increase investor OCI (rather than } \\
\text { profit) } \\
\text { Dividend: Increase investor OCI } \\
\text { Disposal: Increase investor OCI }\end{array}$ \\
\hline
\end{tabular}

\section{ACCOUNTING TREATMENT FOR INVESTMENT PORTFOLIOS OF STOCKS}

The investor company may invest in the other stocks directly by buying each investee company's shares or indirectly through purchasing investment portfolios. Investment portfolios are treated in the same way as the individual investee company is. In other words, if the investor controls or has significant influence on the investment portfolio, investment portfolio is regarded as the long-term equity investment. Otherwise, it may be treated as a financial asset. "Table IV" concludes accounting treatment for investment portfolios of stocks.

TABLE IV. ACCOUNT Summary For INVESTMENT PORTFOlio of StOCKS

\begin{tabular}{|l|l|l|l|}
\hline \multicolumn{1}{|c|}{ Investment type } & Account on balance sheet & \multicolumn{1}{|c|}{ Investee type } & \multicolumn{1}{c|}{$\begin{array}{c}\text { Account on income } \\
\text { statement }\end{array}$} \\
\hline $\begin{array}{l}\text { Investment portfolio } \\
\text { management type }\end{array}$ & Financial assets & $\begin{array}{l}\text { e.g. Invest in asset } \\
\text { management plan or } \\
\text { collective trust scheme }\end{array}$ & $\begin{array}{l}\text { Depending on investment } \\
\text { classification on balance } \\
\text { sheet }\end{array}$ \\
\cline { 2 - 3 } & Long-term equity investment \\
\hline
\end{tabular}


[9] Han Yan, Cui Xin and Guo Yan, 2015, A Study on the Motives of the Chinese Listed Firm's Stock Investments [J], Journal of Management Science 28(04), 120-131.

\section{BANK FINANCIAL PRODUCT INVESTMENT AND PERFORMANCE REPORTING}

Bank financial products in China can invest in a wide range of securities including stocks. It is controversial in literature which account the invested bank financial products belong to on the balance sheet. Bank financial products are invested for different purposes with different types of cash inflows, durations and risks. According to the different features of bank financial products, the investments may be recorded in the account of "other money and money equivalent", the account of "financial assets measured at fair value whose changes are included in other comprehensive income", the account of "financial assets measured at fair value whose changes are included in current profits and losses", the account of "financial assets at amortized cost" [12], or the account of "other current assets" [13]. The incomes from the invested bank financial products are recorded in the investment income.

\section{CONCLUSION}

This paper discusses different types of stock related investments that listed firms in the Chinese A-share market are investing in, and summarizes how the investee company performances affect the investor company's accounts on the income statements. The paper also compares Corporate Accounting Standard No.22 for Enterprises- Recognition and Measurement of Financial Instruments in 2006 with the revised new accounting standards in 2017, and analyzes the main effects of the new accounting standards. Besides, accounting treatment for bank financial products, which is a controversial issue in literature currently is discussed in this paper.

\section{REFERENCES}

[1] Wu Zhanchi and Li Xiaolong, 2011, Corporate Governance, Investor Emotion and Over-investment on Securities [J], Finance \& Economics 12, 74-81.

[2] Corporate Accounting Standard No.2- Long-term Equity Investment, 2014, issued by Ministry of Finance of the People's Republic of China.

[3] Corporate Accounting Standard No.22 Recognition and Measurement of Financial Instruments, 2017, issued by Ministry of Finance of the People's Republic of China.

[4] Annual Financial Report of Shanghai RAAS Blood Products Co., Ltd., 2017 , retrived from http://www.raascorp.com/upload/20180510103516fj_groupcopy1.pdf.

[5] Annual Financial Report of Changsheng Bio-technology Co., Ltd., 2017 , retrived http://pdf.dfcfw.com/pdf/H2_AN201805281149881715_1.pdf.

[6] Wang Qichao, 2019, Thoughts for the Effects of the New Accounting Standards of Financial Instruments on Equity Investments without Significant Influences [J], The Chinese Certified Public Accountant 08, 89-92.

[7] Corporate Accounting Standard No.33- Combined Financial Statements, 2014, issued by Ministry of Finance of the People's Republic of China.

[8] Corporate Accounting Standard No.22- Recognition and Measurement of Financial Instruments, 2006, issued by Ministry of Finance of the People's Republic of China.
[10] Wu Zhanchi, 2009, A Research on the Management of Securities Investment Earnings-empirical Evidence from China Securities Market [J], Economic survey 3,134-136.

[11] Liu Yu, 2019, Methods to Evaluate the Success of Company Shortterm Stock Investment under the Accounting Standards in 2006 in China and Improvements under the Accounting Standards in 2017, 4th International Conference on Economy, Judicature, Administration and Humanitarian Projects (JAHP 2019) 94, 586-590.

[12] Huang Shihua, 2018, Research on Accounting Treatment for Corporate Investment in Bank Financial Products [J], China Collective Economy 34,70-71.

[13] Wang Min, 2018, Analysis of Accounting Treatment and Reporting of Bank Financial Products [J], China Township Enterprises Accounting 04, 38-39. 